\title{
The Three Seas Initiative and the Graz Triangle Relations Towards the United Arab Emirates
}

\author{
ADAM KRZYMOWSKI \\ Zayed University
}

\begin{abstract}
Summary
The presented research is the first such study on Austria, Croatia, Slovenia (Graz Triangle) as a part of the Three Seas Initiative from the perspective of the United Arab Emirates. After 2015, when the Three Seas Initiative was initiated, the United Arab Emirates greatly intensified its relations with this geographical area. In this study, the author relied on international practice and role theory, supported by the analytical and empirical case study method. Moreover, the researcher verified the study results through ten-year participation in many processes and phenomena of the investigated area, including as Ambassador, Senior Advisor to Dubai Expo 2020 responsible for strategies and dynamizing the Three Seas Initiative countries' relations with the United Arab Emirates. The obtained findings indicate that the Graz Triangle states have the potential for further relations development with the United Arab Emirates. However, to give its strategic significance, the implementation project should be within a broader formula, i.e., the Three Seas Initiative.

Keywords: Austria, Croatia, Slovenia, Graz Triangle, United Arab Emirates, Three Seas Initiative
\end{abstract}

\section{Introduction}

Graz is a city in today's Austria. It was established on the site of a Slavic settlement bearing the same name. Graz in Slovenian means a small castle. The history of the city is closely related to both Austria, Croatia, and Slovenia. From the very beginning of its existence, it had the character of a stronghold. Additionally, a fortress was built in defence against the Turks at the turn of the 15th and 16th centuries. In the 21 st century, in 2013, after Croatia joined the EU, the heads of the three governments met in the Grazer Burg castle. They decided to establish a new form of cooperation called the Graz Triangle. This term is not yet part of academic and deep 
public discourse. However, according to the research author, this project should be a significant platform of cooperation, and not just focus on neighbourhood relations. It should be developed in terms of the Three Seas Initiative (3SI), and the Union for the Mediterranean. In this context, it is crucial to investigate dynamics relations between Austria, Croatia, Slovenia with partners which have recognised both initiatives and regions as a part of their strategy. The United Arab Emirates (UAE) has been that international player for a number of years.

The study object is the relations of Austria, Croatia, and Slovenia (Graz Triangle) with the UAE, which initiated the development of relations with Zagreb and Ljubljana just after the announcement of the 3SI. Also, Austria has had an advanced relationship with the UAE almost since the state's inception. It implements ambitious engagement plans in the MENA area. The 3SI, announced in 2015 and covering 12 member states, forms a geopolitical triangle between the Adriatic, the Baltic, and the Black Sea, which involves cooperation at the highest political level. The 3SI should be seen not only from the perspective of cooperation between 12 countries. But also, in the external dimension, between the EU and each participant of this initiative. The 3SI means that the region has more to offer. Thus, it raises the possibilities of their influence in international relations, including non-European partners, such as the UAE. In 2015, the same year, just before the announcement of the 3SI, two Adriatic countries (3SI members) received enormous capital for implementing its strategy towards the UAE and jointly influence the global arena. In September 2015, the UAE Mister of Economy Sultan Bin Saeed Al Mansouri visited Slovenia for the first time and both countries signed an agreement on economic cooperation. In July 2017, there was a historic visit to Croatia. At that time, the UAE Minister of Foreign Affairs and International Cooperation, H.H. Shaikh Abdullah Bin Zayed Al Nahyan met with the President of Croatia, Kolinda Grabar-Kitarović, and Prime Minister, Andrej Plenković.

This study aims to find an answer to the research question of whether the relations of the three countries of the Graz Triangle with the UAE have the potential for deeper and broader dynamics of their creative development with the impact on the implementation of the 3SI and the Middle East. The answer to this question relates to the strategic vision of the 3SI. The search for an answer to this research question requires a critical analysis of processes, new phenomena, and changes taking place both in the transatlantic area and in the region of the Middle East and North Africa. Therefore, both researchers and practitioners of international relations will benefit from this analysis. The topic discussed is of exceptional research significance because it is the first study on Graz Triangle countries' relations with the UAE from the 3SI perspective, which has greatly intensified their relations with this geographical area after 2015. This empirical research and its findings are the result of 10 
years of the author's participation, not only by observation, in many cooperation initiatives between 3SI countries and the UAE, among others, as an Ambassador, Senior Advisor to Dubai Expo 2020, also responsible for strategy and dynamizing the relations of all $3 \mathrm{SI}$ countries with the UAE.

\section{Theoretical Framework}

Along with the 3SI development, there are increasing scientific studies and analyses on this issue. However, so far there is no 3SI study in terms of the Graz Triangle and its member states' relations with the UAE. Therefore, this study is a contribution to the development of research on the 3SI, Central and Eastern Europe, and the UAE.

The theory of international practices is an appropriate analytical tool to study the cooperation between the UAE and the Graz Triangle belonging to the 3SI. Practices are the focus of international relations analysis, as underlined by many researchers, including Barnett and Finnemore's Rules (2004) and Ringmar (2014). International practice theory has been defined by Bueger and Gadinger (2014) as concepts that arise through the application of practitioners' analyses and their transposition into international relations theory to explain them better (Turner, 1994, p. 43). As Schatzki $(2001$, p. 2) rightly points out, there is no uniform approach to practice. For some researchers, such as Schatzki, Cetina, and von Savigny (2001), practice is a category of analysis that produces concepts, called 'theory of practice'. Its crucial element is the activity of actors in international relations, both in bilateral and multilateral relations. International practice theory is not a 'conventional theory', but, by studying practice, it provides a creative space for discussion among international relations researchers. Therefore, international practice theory can be applied to international relations generating a new approach. It should also be noted that the researcher combines understanding practices 'from within' and 'from outside'. Therefore, Pouliot (2007), combining subjectivity and objectivity in conducting research, proposed a 'subjectivist' methodology. Moreover, it should be noted that the analysis of practices takes place through the prism of the researcher's practices. As Bourdieu (2004) emphasizes, in this way, a process of reflection follows the cornerstone of the methodology of the practice theory.

However, international practice theory has a drawback in the context of this article. The researcher is in a delicate position between distance and commitment. Therefore, the author of the article adopted the role theory in international relations, which helps explain minilateralism. There is a concept that emphasizes the ability to forge alliances. This concept in the context of international relations was one of the first used by Fritsch (1988) in the 1980s. However, the development of this concept took place in the 21 st century, especially after the global financial crisis. It was then 
that Naím (2009) began to emphasize that smaller alliances are more effective in solving problems. The presented article analyses the Graz Triangle as an example of minilateralism and the bilateral relations of their members from the perspective of the role theory. This concept began to be applied in the early 1970s. However, a few years later, Rosenau (1981) presented the state's role analysis in terms of its foreign policy and adaptation to international changes. The role theory emphasizes defining the state role according to its potential and self-determination of one's position in relation to the strength of influence and the position of partners with whom they interact (Conway \& Feigert, 1987, pp. 136-139). Also, the so-called interactive approach shows how the dynamic relationships between states determine their roles and positions. Moreover, the participants of the interaction create different positions and roles in this system. As Keohane (2012, p. 19) emphasizes, interaction with other countries determines their roles. They are also defined by activities aimed at the implementation of joint projects.

The adopted international practice and role theories help to understand this research area. In this way, the applied concepts bring the researcher closer to finding the answer to the adopted research question. At the same time, the author of the article assumed that it should be enriched and tested with appropriate research methods. Therefore, the researcher verified the theoretical assumptions using a comparative analysis of three case studies of bilateral relations between the Graz Triangle countries and the UAE. The main categories of comparison are visits by highlevel representatives of countries, the dynamics of trade, joint projects, and the political will to develop relations. The case studies adopted are analytical and empirical. Therefore, qualitative methods have been used, aimed at causal explanation and interpretation. The adopted method of case analysis aims to find an answer to the research question by examining the sequence of events, starting from their causes and ending with the observed effect. Each of the three Graz Triangle countries, Austria, Croatia, and Slovenia, has been tested in relations with the UAE. Due to the novelty of the presented project, the collected research material is based mainly on information from government institutions of the studied countries. The main reason for conducting this research based on this type of information source is the lack of research on the relationship between the Graz Triangle countries and the UAE in the literature. Then, the collected research material became the subject of analysis, critical evaluation, and comparison. As a result of this process, findings were developed. Moreover, the author of the presented article had the opportunity to verify the results based on personal participation and direct observation of the phenomena occurring in the area of development of UAE relations with Austria, Croatia, Slovenia, and other countries belonging to the 3SI. Therefore, the adopted research methods, combined with the author's experience and direct participation in the ana- 
lysed processes, resulted in the scientific research in question. It contributes to the development of the science of the discussed research area.

\section{Graz Triangle - 3SI - UAE}

The research analyses the bilateral relations of the Graz Triangle states with the UAE. The importance of minilateralism, such as the 3SI or Graz Triangle, should be emphasized in contemporary international relations. They provide participating countries additional opportunities to pursue their own interests in broader projects that consider specificities and balance influences. Coordinated minilateralism in the form of the Graz Triangle may bring greater possibilities of influencing other 3SI partners. Moreover, Croatia and Slovenia are the only 3SI members located in the Adriatic Sea region. They will be able to emphasize the role and importance of this Adriatic dimension of the 3SI. Thus, they will become more influential players in the Mediterranean and the Middle East. This, in turn, will be a positive value for the effective implementation of the goals of their foreign and security policies. From the UAE interests' point of view, the Graz Triangle countries are a source of searching for new projects to implement the UAE 2030 vision, which is based on green economy and new technologies. From the geopolitical point of view, the development of these relations is part of the construction of in-depth relations and alliances, which will make it possible to effectively stop Turkey's ambitious plans towards the Mediterranean and the Middle East.

\subsection{Graz Triangle}

As a result of European integration processes, since 1 July 2013, when Croatia acceded to the European Union, all three countries are members of this organization. Croatian foreign policy for years focused on joining the EU, and on solving bilateral problems related to Yugoslavia's collapse. Croatia's accession to NATO (2009) and the European Union (2013) is associated with the need to optimize the formula for pursuing national interests within the new political framework. Croats emphasize that with Euro Atlantic area integration, their country is symbolically leaving the Western Balkans region. Due to historical ties, Central Europeanness is often contrasted with Balkanness in Croatian political thought ('flight from the Balkans'). The relation with Central Europe from the Croatian perspective also concerns ties with Austria and Slovenia. In this process, cooperation with Central Europe gained increasing importance (Sadecki, 2013). In August 2013, Austria, Croatia, and Slovenia's heads of government met at the Grazer Burg castle. It happened soon after Croatia joined the European Union. During the meeting, the Austrian Chancellor Faymann emphasized the trilateral cooperation significance for the European integration processes. Therefore, the leaders decided to continue the ties between 
Austria, Croatia, and Slovenia in the Graz Triangle framework. All heads of government agreed that the economic field would be the crucial area of their closer cooperation. Moreover, all three countries share a common history and culture (Radio.net Zadnja izmjena, 2013). In order to deepen bilateral relations, especially in the economic field, and to coordinate their joint positions in the EU, meetings of the heads of government of the Graz Triangle began to be held twice a year. In March 2015, Austria, Croatia, and Slovenia's heads of government and the European Union Commissioner for Energy met to discuss regional energy cooperation and the European Energy Union. The tripartite meeting of Austrian Chancellor Werner Faymann, Croatian Prime Minister Zoran Milanović, and Slovenian Prime Minister Miro Cerar took place in the Austrian ski resort of Schladming. The European Union Commissioner for Energy, Maroš Šefčovič, also participated in the meeting. The Croatian head of government emphasized that the priority of his country's policy was the construction of the liquefied natural gas (LNG) terminal on the island of Krk and the building of the European Energy Union. Moreover, the latter was part of the joint European Union interest. This project was included in the plan of the European Commission (Vlada, 2015).

\subsection{The Three Seas Initiative}

The 3SI was initiated in 2015 and formally launched in 2016, during the first summit in Dubrovnik, Croatia. On the Croatia and Poland initiative, the 3SI was established as a forum for cooperation between 12 countries: Austria, Bulgaria, Croatia, the Czech Republic, Estonia, Hungary, Lithuania, Latvia, Poland, Romania, Slovakia, and Slovenia. During the project's inaugural summit, the leaders adopted a joint declaration in which they agreed to deepen cooperation in the Adriatic-Baltic-Black Sea area, both in the internal dimension of the EU and in the wider transatlantic perspective. The participants of this project decided to cooperate specially in the areas of energy, transport, digitization, and economy. The 3SI has been identified as the 'New Europe' concept implementation, from Estonia to Croatia, and a geopolitical alliance of the new NATO and EU member states. Except for Austria, the participating countries have a history of communism. Moreover, this concept refers to the geopolitical idea of the Intermarium, a federation of independent states in Central and Eastern Europe, based mainly on the principle of ethnicity. Today's initiative also aims to limit Russia's influence in the region. For this purpose, 3SI member states are an excellent strategic choice for the USA and NATO as the guarantor of their security (Kurečić, 2018, pp. 99-100).

The European Union emphasized the development of East-West cooperation, ignoring the North-South communication and energy corridors. The 3SI founders intend to develop cooperation in the Central and Eastern Europe area complemen- 
tarily (Górka, 2018). During the next Three Seas summit in Warsaw in 2017, the President of Croatia, Kolinda Grabar-Kitarović, emphasized that the LNG terminal on the Croatian island of Krk was a strategic project for energy independence not only for Croatia itself but for the entire region. It would be ensured by the construction of a corridor with Poland and the reverse, and interconnectors towards Hungary and Ukraine. Moreover, US President Donald Trump, who was present at the summit, emphasized the strategic importance of the 3SI. The meeting in June 2019 in Ljubljana was attended by the German President, Frank-Walter Steinmeier, as the leader of the partner country, and the American Energy Minister Rick Perry (PolskieRadio24.pl, 2019).

In 2019, Hungary announced readiness to import LNG from Qatar via Croatia in 2021, when the LNG terminal on the island of Krk will start operating. During his visit to Qatar on 22 October 2019, Hungarian Minister of Foreign Affairs Peter Szijjarto emphasized preparation. Purchase of LNG from Qatar reduces dependence on Russian raw material (Jakóbik, 2019). On 15 June 2020, LNG Croatia, implementing the floating terminal project on the island of Krk, announced that the facility's regasification capacity was almost fully booked for the years 2021-2023. It was influenced by the Qatar gas and electricity company Powerglobe Qatar LLC's decision to reserve approx. $10.1 \mathrm{bcm}$ of capacity in the period from January 2021 to the end of September 2035. It was Croatia's success, as well as the implementation of 3SI assumptions and employment of one of the most significant projects diversifying gas supplies to South-Eastern and Central Europe. However, without the support of the US, the project probably could not be completed. From the American interests' point of view, the LNG terminal on the Croatian island of Krk also reduces Russia's influence. Moreover, it enables the sale of American LNG in the region and an increase in its revenues (Seroka, 2020). On 29 January 2021, Croatian Prime Minister Andrej Plenković officially inaugurated the new LNG terminal on the island of Krk in Croatia, including a pipeline. The construction of this LNG terminal and the connecting Omišalj-Zlobin gas pipeline received EU financial support of EUR 124 million under the 'Connecting Europe Facility' (CEF). Dirk Beckers, Director of the Executive Agency for Innovation and Networks (INEA), emphasized that the Krk LNG terminal would be of strategic importance for the security and diversification of natural gas supplies in Central and South-Eastern Europe. In addition, this project is a priority for the European Union under the Energy Connectivity initiative (European Commission, 2021).

\subsection{The United Arab Emirates}

The UAE remains a strategic partner for major transatlantic actors, including the United States. Both countries signed new agreements, in 2017, on cooperation in the field of security, and in 2019 in defence. There are about 5,000 American sol- 
diers located in the UAE. In the 2015-2019 period, this country bought from the US about $70 \%$ of its weapons. Since 2014, the UAE is the first Arab country to have its Ambassador at NATO headquarters. The UAE has been consistently and dynamically developing relations with the European Union and its new member states for over 10 years. In order to develop and deepen relations with the EU, in January 2018, the UAE signed cooperation agreements between the Ministry of Foreign Affairs and International Cooperation of the UAE and the European External Action Service. It involves cooperation in areas such as trade, innovation, research, education, transport, environment, health, consumer protection, and multilateral cooperation. In July 2019, in Brussels, the first meeting between the UAE diplomatic service and the European Union took place, as part of the political dialogue. In addition to economic issues and the EU presence at Expo 2020 Dubai, partners discussed the issues of combating terrorism and cooperation for humanitarian aid. Moreover, the meeting participants discussed the challenges related to the peace process in the Middle East, the situation in Syria, Yemen, and Sudan, as well as in Libya, Iraq, Afghanistan, the Horn of Africa, and the Sahel. As a result of the dynamic development of relations, in January 2020 in Brussels, H.H. Sheikh Abdullah bin Zayed Al Nahyan, UAE Minister for Foreign Affairs and International Cooperation, met with the High Representative of the European Union, EU Foreign Affairs and Security Policy, and Vice-President of the European Union Commission, Josep Borrell. The talks focused on the most significant strategic challenges related to the Middle East (Krzymowski, 2020a, pp. 52-54). Relations with Central and Eastern Europe are becoming more dynamic. The UAE pursues strategies to diversify both alliances and sources of income. Although the sale of crude oil remains a crucial item of the federal budget revenues, efforts are being made to become independent from this raw material. Therefore, the UAE is investing in green economy and renewable energy sources. Abu Dhabi is home to the International Renewable Energy Agency.

On 15 September 2020 in Washington, the UAE signed agreements to establish diplomatic relations with Israel. Under the agreement, both countries, apart from establishing diplomatic relations, opened embassies and direct air connections. In addition, cooperation has started in several areas, including investments, trade, tourism, research, education, and energy. Security cooperation is a significant element of the new situation. A crucial part of the deal is the transfer of American and Israeli advanced weapons to the UAE. The UAE is primarily interested in acquiring the F-35 multi-role aircraft. Moreover, both countries started to cooperate in combating cyber threats. Additionally, the UAE has expressed interest in working closely with Israel in the East Med Gas Forum. A week after the signing of the UAE-Israel Agreement, the Eastern Mediterranean Gas Forum Charter was adopted, which formally confirms the founding of a new international organization based in Egypt. 
The signatories of the agreement are Cyprus, Egypt, Greece, Israel, Jordan, and Italy. The Palestinian Authority is also a participant in the forum. France applied for accession and was accepted. The United States, the European Union, and the UAE have applied for the organization observer status. On 9 March 2021, the Forum Charter entered into force. These activities cause the dynamics of new geopolitical changes in the Middle East, including the Mediterranean area, with the participation of the UAE (Jakóbik, 2020). In 2021, the UAE celebrates its 50th anniversary. For the UAE, an important project to develop and deepen with multiple partners in the international arena is Expo 2020 Dubai, which will take place between October 2021 and March 2022. It is the first EXPO World Exhibition in the Middle East, Africa, and South Asia region. The organizers adopted 'Connecting Minds, Creating the Future' as their slogan. The Expo in Dubai also has three main themes, i.e. Sustainability, Mobility, and Opportunity. This project is a crucial element for the UAE Soft Power Strategy implementation, adopted in 2017. Based on Expo 2020, organizers want to create an extensive global cooperation network with both state and non-state actors (Krzymowski, 2020b, pp. 9-10).

\section{Case Studies}

\subsection{Austria}

Austria, of all 3SI countries, has the longest diplomatic relations with the UAE, starting in 1974, three years after the founding of this state. In the Gulf region, the UAE is Austria's largest trading partner. In addition, Vienna treats the UAE as a business hub serving the area of the Gulf Cooperation Council (GCC), North, and East Africa as well as a part of the Indian subcontinent. About 330 Austrian companies are operating in this country. In the last few years, they have gained tremendous dynamics at the highest levels (Austrian Embassy in Abu Dhabi, 2020a). In May 2017, the Chancellor of Austria Christian Kern paid a visit to the UAE to further strengthen cooperation in the fields of economy, trade, and energy (MOFAIC, 2017b). A few months later, in November 2017, the 9th UAE-Austria Joint Committee took place in Vienna. The Emirates side emphasized the strategy implementation to diversify UAE revenue sources and build a knowledge-based economy. In this sense, UAE representatives stressed the desire to establish strategic partnerships with innovative projects. At the end of the committee meeting, representatives of both countries signed an MoU on industrial cooperation in energy technologies (MOFAIC, 2017c). After less than three months, the Minister of Foreign Affairs and International Cooperation, H.H. Sheikh Abdullah bin Zayed Al Nahyan, paid an official visit to Austria, where he met with Chancellor Sebastian Kurz, among others. The visit's purpose was to strengthen relations and discuss common interests in regional and global dimensions (MOFAIC, 2018a). A few months later, in April 2018, Austrian Chancellor Sebastian 
Kurz paid an official visit to the UAE. During the visit, a 40-year contract was signed between the Abu Dhabi National Oil Company (ADNOC) and the Austrian Mineral Oil Administration (Österreichische Mineralölverwaltung - OMV AG), an Austrian corporation operating in the oil and gas area. Under the contract, the Austrian company for \$ 1.5 billion received a 20\% share in the concession for Satah Al Razboot fields (SARB) and Umm Lulu oil fields offshore in the Emirate of Abu Dhabi (MOFAIC, 2018b). Moreover, nine months later, in January 2018, Austrian Finance Minister Hartwig Löger came again to the UAE to participate in the signing of another contract between the same companies. The agreement concerned the acquisition by OMV AG of a 15 percent stake in ADNOC Refining and the emerging global Trading Joint Venture (Austrian Embassy in Abu Dhabi, 2020b). After less than a year, in March 2019, the Austrian Chancellor, Sebastian Kurz, paid another visit to the UAE, during which were signed two further contracts of ADNOC and OMV AG in new areas in the field of petrochemicals. Moreover, ADNOC and Borealis signed an agreement regarding cooperation on global markets in the area of the integrated polyolefin industry. It is worth noting that since 1998, both companies have a joint venture in the petrochemical company Borouge with headquarters in Abu Dhabi, which is a leader in innovative plastic products for several industries (MOFAIC, 2019).

\subsection{Croatia}

Diplomatic relations between the Republic of Croatia and the UAE were concluded on June 23, 1992. From then until 2017, no particular dynamics of relations between the two countries were recorded. Neither Croatia nor the UAE have diplomatic missions. The UAE ambassador in Germany is accredited to Croatia. The Ambassador of Croatia in Egypt covers the UAE. However, in July 2017, there was a breakthrough when the Minister of Foreign Affairs and International Cooperation, H.H. Shaikh Abdullah Bin Zayed Al Nahyan, arrived for the first time in Croatia. During the visit, a discussion was held with the President of Croatia, Kolinda Grabar-Kitarović, Prime Minister Andrej Plenković, and Deputy Prime Minister and Minister of Foreign and European Affairs Marija Pejčinović Burić, on establishing closer economic relations. The Croatian side emphasized that the natural gas project, which was being developed, should be an interesting area of cooperation and investment for the UAE. Moreover, partners discussed global challenges, recent international events, the situation in Libya, and the illegal immigrant crisis. Additionally, during a meeting with the Minister of Finance, Zdravko Marić, an agreement was signed that would help avoid double taxation (Gulfnews, 2017). The next favourable event for the relationship between the two countries was, at the same time, in July 2017, the inauguration of the Emirates airline connection between Dubai and Zagreb. In April 2018, a Croatia-UAE forum was held in Zagreb, which was attended by 15 UAE companies and 70 Croatian entities representing 
the food industry, pharmaceuticals, metal processing industry, electrical engineering, construction, and finance. During the meeting, it was decided that many Croatian companies would participate in the Dubai Expo as an enormous opportunity for their promotion (HINA, 2018). In 2019, Zagreb notified that the Croatian Embassy in the UAE would be opened soon.

\subsection{Slovenia}

Slovenia and the UAE established diplomatic relations in 1992. However, until 2015 they did not have any dynamics. In September 2015, the first visit of UAE Minister of Economy Sultan Bin Saeed Al Mansouri to Slovenia took place. The Minister with his counterpart Slovenian Minister of Economic Development and Technology, Zdravko Počivalšek signed an agreement on economic cooperation. The talks focused primarily on developing cooperation in construction, housing equipment, food, and tourism, in environmental protection, innovation, renewable energy sources, and the food industry. Moreover, partners also signed an agreement on Cooperation in Civil Aviation (The Slovenia Times, 2015). During the meeting with the Prime Minister of Slovenia, Miro Cerar, both sides expressed interest in supporting cooperation in areas such as tourism, infrastructure, investment, IT, innovation, and industry. Besides, it was emphasized that the UAE is ready to share its world-class experience in operating ports and free zones with Slovenia (Gulfnews, 2015). In September 2016, the Slovenian Minister of Development and Technology, Zdravko Počivalšek, accompanied by nearly 200 business representatives, visited the Dubai Chamber of Commerce and Industry and the Chamber of Commerce. The UAE Minister of Economy Sultan Bin Saeed Al Mansouri stressed that his country continued to expand and deepen relations with Europe and Slovenia which had become a significant element of the strategy. There are great cooperation opportunities, especially in engineering, energy, interior design, food products and services, ITC, tourism, and agriculture. In the context of a knowledge-based economy, he also emphasized that small and medium-sized enterprises need support. The president and CEO of the Dubai Chamber, on the other hand, indicated their readiness for joint investments in such areas as trade, tourism, logistics and transport, sustainability, and renewable energy. It was Slovenia's first trade and investment mission to the UAE. Slovenia, bordering Austria, Italy, Hungary, and Croatia proposed the UAE to be a gateway to the 3SI area (Dubai Chamber, 2016). In the subsequent development of the relationship, Slovenian Prime Minister Miro Cerar came to the UAE in February 2017 (MOFAIC, 2017a). In October 2019, the UAE-Slovenia Joint Committee meeting with the Minister of Foreign Affairs as the head of the Slovenia delegation took place in Abu Dhabi. During his visit, both sides emphasized the need to treat one another as a pivotal point for further economic expansion (Salman, 2019). Additionally, the talks emphasized the role and 
importance of ITF - Enhancing Human Security, an organization from Slovenia that, among others, is involved in the Middle East in land mine clearance and postconflict reconstruction, as well as cooperation on projects in business, logistics, science, and artificial intelligence (Hussein \& Hatem, 2019). At the meeting with the Minister of State for International Cooperation, Reem Al Hashimy, both parties confirmed their interest in developing cooperation for sustainable development and environmental protection as part of the Green Group of six small countries, founded in 2009 by Slovenia and of which the UAE is also a member. Moreover, the interlocutors agreed to establish lasting cooperation between experts of both countries in the field of artificial intelligence (Embassy of Slovenia, 2019). During the visit, the Minister of Foreign Affairs Miro Cerar also officially inaugurated the embassy activities in Abu Dhabi. It was the first in the Gulf and it began operating in 2018 (Total Croatia News, 2019). Deputy Prime Minister and Minister of Foreign Affairs of Slovenia, Miro Cerar, after less than two months, in January 2020, once again came to the UAE. During a conversation with the Minister of Foreign Affairs and International Cooperation, H.H. Sheikh Abdullah Bin Zayed Al Nahyan, readiness to cooperate in the field of renewable energy was emphasized (Hassan, 2020).

\section{Findings}

The results of the empirical part of this research show the dynamics of bilateral relations between 3SI countries, including the Graz Triangle, and the UAE. The findings focus on the implementation of visits between states and the development of trade exchange, showcasing the exports of 3SI countries to the UAE. It should be noted that when analysing the balance of trade for the Graz Triangle countries and the UAE, import from these countries is very low. The UAE in trade with Austria recorded a negative level of non-oil trade balance every year in the 2011-2019 period, between nearly -600 to over -1,100 (in USD Millions). In Croatia's case, import from the UAE is noticeable due to the purchase of unwrought aluminium. However, throughout the analysed period, the UAE also recorded a negative non-oil trade balance, between over -10 and nearly -60 . In the case of Slovenia, the difference is even higher, from over -60 to over -80 (Ministry of Economy, 2021). At the same time, the acceleration of the state visits of the Graz Triangle states with the UAE goes hand in hand with the development of the trade dynamics.

\subsection{Relations with the UAE: Comparison}

The analysis of bilateral relations between the Graz Triangle states shows that Austria has the longest and richest history of ties with the UAE. Vienna established diplomatic relations with the UAE 18 years earlier than Croatia and Slovenia. At 
Figure 1. The Most Important Official Bilateral Visits of Graz Triangle Countries with the UAE in the 2016-2020 Period

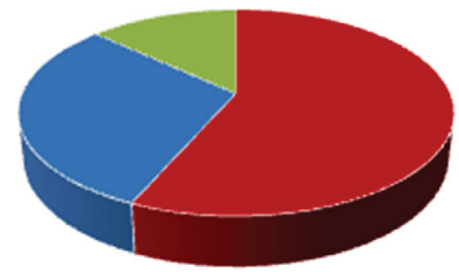

\section{- Austria - Croatia ॥ Slovenia}

Source: elaboration of the author - based on data from government institutions

that time, these states did not exist as separate entities. Therefore, Austria shows a higher dynamic of relations with the UAE than Zagreb or Ljubljana, visible mainly in trade in the period between 2011 and 2019. The nature of economic relations also reflects their deep dimension. One example is the Austrian oil and gas corporation Österreichische Mineralölverwaltung (OMV AG) contract with the Abu Dhabi National Oil Company (ADNOC) for a 20\% share in the offshore oil concession in the Emirate of Abu Dhabi, for a 40-year period. Moreover, both countries are developing cooperation in the energy sector, specifically in the field of renewable energy.

Analysing the most significant bilateral visits in the 2016-2020 period, considering heads of state and government, ministers of foreign and economic affairs, after the start of the 3SI, the situation of Croatia and Slovenia looks much better. Zagreb and Ljubljana began developing their relationship with Abu Dhabi. A breakthrough event in Croatia's relations with the UAE was in July 2017 in Zagreb, the first visit of the Minister of Foreign Affairs and International Cooperation of that country, H.H. Shaikh Abdullah Bin Zayed Al Nahyan. During the meetings at the highest levels, the UAE's chief of diplomacy, among other things, expressed his country's interest and readiness to invest in the gas project. On the other hand, after the announcement of the 3SI inauguration, in September 2015, the groundbreaking visit of the UAE Minister of Economy, Sultan Bin Saeed Al Mansouri, took place in Slovenia. This visit initiated the higher dynamics of ties between both countries. The dominant topic has been the economy with a focus on renewable energy resources, artificial intelligence, and the IT sector. The UAE offered support in Slovenia's seaport development. Ljubljana, on the other hand, offered itself as a gateway to the 3SI area. This study shows that Croatia and Slovenia, taken together 
Figure 2. Export of Graz Triangle Countries to the UAE in US \$ (in thousand)

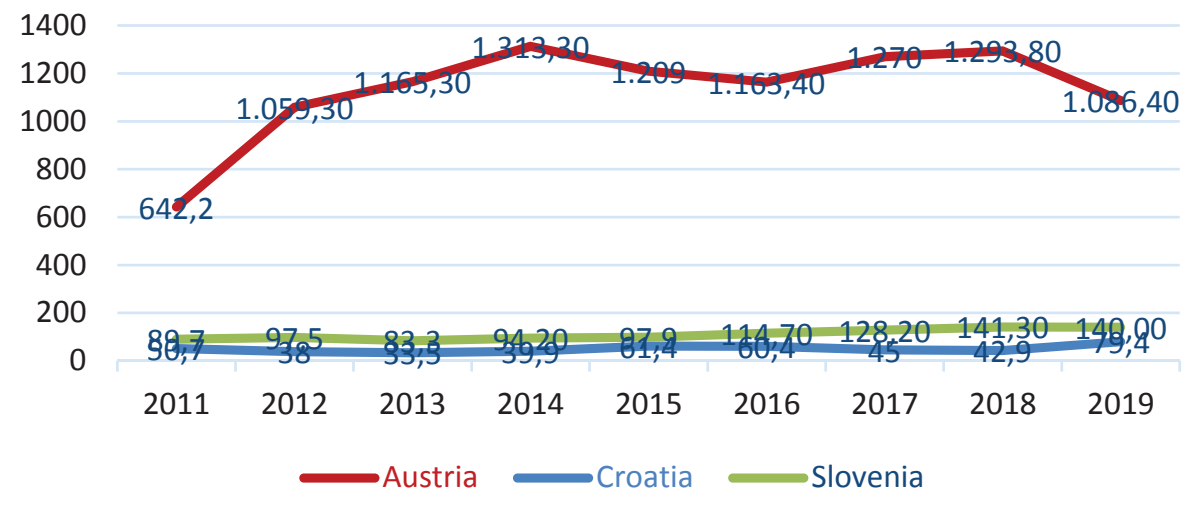

Source: elaboration of the author - based on data from government institutions

in the 2016-2020 period, have significantly increased their high-level visits when compared to Austria. While there is also a gradual change in the level of exports for these two countries, they are relatively low when compared to those of Austria, as presented in Figure 2.

The research results indicate that all the Graz Triangle countries can develop economic relations with the UAE, including in the field of energy. The UAE is implementing Vision 2021, supporting a green economy program under the slogan: Green economy for sustainable development, which was adopted in January 2012. Thanks to it, the UAE is building a new global model of green economy. Thus, the UAE aims to be a world leader in new green technologies. To this end, it consistently adopts new strategies and programs, and is active in the international arena. The UAE, when investing in green economy, primarily focuses on the development of renewable energy and wants to become an international hub in this field (Krzymowski, 2020c, p. 213).

An analysis of the last ten years of the twelve 3SI countries shows that all countries, except Poland, demonstrate dynamic relations with the UAE. Although the Czech Republic has not had any official, high-level bilateral visit since 2016, the country maintains high export dynamics, unlike Poland. Figure 3 presents the dynamics of the most significant official bilateral meetings. It includes visits at the heads of state and government level, as well as ministers of foreign affairs, economy, and royal family members in high state positions.

Concerning exports to the UAE, the only significant decrease was recorded in the case of Poland and Hungary. However, in Hungary, since 2015, there have been 
Figure 3. The Most Significant Official Bilateral Visits of 3SI Countries with the UAE in the 2011-2020 Period

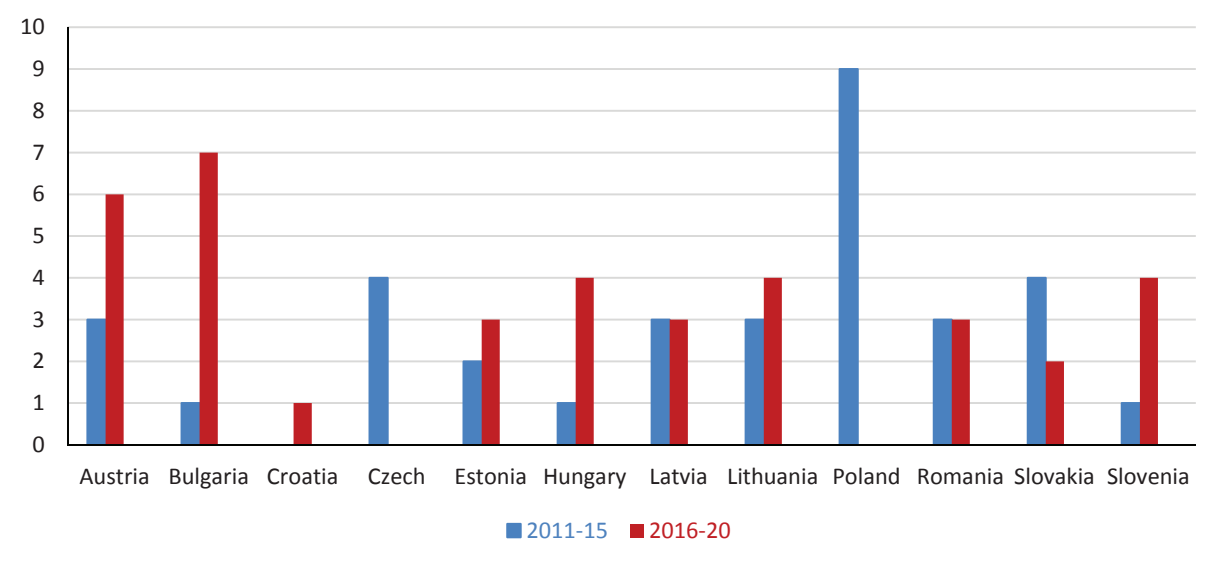

Source: elaboration of the author - based on data from government institutions

high dynamics of economic visits at the ministerial level and Joint Economic Commission meetings, which should soon bring positive results.

In the years 2011-2015, Poland initiated closer cooperation with a new dynamic of visits and relations between the UAE and Central and Eastern European countries. After the 3SI adoption in 2015, there was an unprecedented revival of political, diplomatic, economic, and cultural relations with the UAE. However, only Poland, the 3SI initiator, significantly weakened its ties. There was a lack in continuity of organizing the Joint Economic Commission meetings that resulted from the economic agreement signed in 2012. In the years 2011-2015, Poland was the clear leader in the dynamics of relations with the UAE, not only concerning the countries being part of the 3SI. After 2015 and the implementation of the 3SI, the situation changed drastically in favour of other countries. However, due to its geopolitical, population, and economic potential, Poland still has the chance to regain its leadership position. All other 3SI countries have, since the beginning of this initiative, developed dynamic relations with the UAE, which is a logistics and business hub for Asia and Africa, and a potential investor in the countries of the 3SI.

It should be noted that there is an enormous potential for further development of political and economic relations between 3SI countries and the UAE, which express great interest in strategic cooperation in this area of Europe. This comes in the context where the UAE is a country anchored in close relations with the transatlantic field, as it is a member of the NATO Istanbul Initiative Cooperation program. 
Figure 4. Export of 3SI Countries to the UAE in the 2011-2019 Period in US \$ (in thousand)

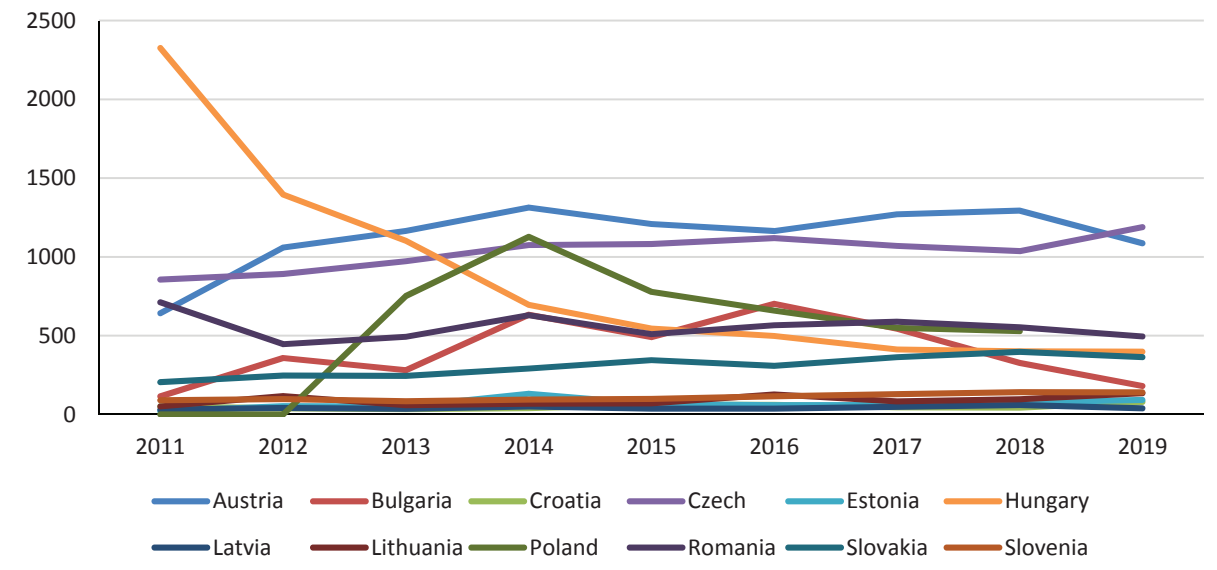

Source: elaboration of the author - based on data from government institutions

Besides, it is the first Arab country to have its NATO-accredited ambassador and has deeper relations with the European Union. Therefore, one should consider that the UAE, which has investment funds, is likely to implement joint 3SI projects which could certainly contribute to the economic dynamism of all parties.

\subsection{The Wider Significance of the Graz Triangle - UAE Relations}

There are dynamic changes in the international environment that determine the conditions for political adaptation. In such circumstances, the state with its own potential will shape its role in the international system. To make it a reality, it implements foreign and security policy strategies. Therefore, the position of the state in international relations is changing. New geopolitical conditions initiated by the collapse of the Eastern bloc and the emergence of Croatia and Slovenia gave a new impulse to research the role of states and other entities in shaping the global order.

Strategic Background

In 1991, after the collapse of the Soviet Union and the American military operation in the Middle East in Iraq, the implementation of the American vision of a 'New Europe' and a new world order began to be implemented by NATO with a new, global vision. In the entire area of interest of the North Atlantic Alliance, the main strategic direction was the southern flank of the Alliance and, as indicated by Volker Rühe (1998), the strategic triangle: the Balkans, the Caucasus, and the Mid- 
dle East / North Africa. When Americans refer to the southern flank of the Alliance, they mean the area that covers everything south of Gibraltar to Iran and what lies between them, namely the Middle East and the Persian (Arab) Gulf. This was where American strategic interests emerged on the southern flank (Asmus, 1997: 51). For the United States, the Persian (Arab) Gulf was the key theatre of operations. First, it was about oil. As a result of such actions, Iraq was excluded from the international oil market for a long time. Second, after the USSR's collapse, the United States sought to reaffirm its role as the sole superpower. The intervention in Iraq was a convenient opportunity to strengthen this role and confirm US hegemony. Third, the United States sought to eliminate Russian and Chinese influence in the Middle East region. Fourth, Washington wanted to end instability in the Middle East region. The territorial disintegration of Iraq and the new political division of the borders in Mesopotamia would be a prelude to this goal. In turn, the inclusion of the North Atlantic Alliance in this game was to be a convenient tool for pursuing US interests. In 1999, shortly after the Washington Summit and the development of a new Strategic Concept, the concept of Europe's southern periphery appeared as NATO's 'near abroad'. The political and economic changes that took place on the world political scene after the collapse of the block system made the countries of NATO's 'region' key actors for the United States in securing its interests on the southern flank of the Alliance. Although Austria is a neutral country, its security strategy emphasizes the demand for active cooperation within the EU's Common Foreign and Security Policy and the European External Action Service (Austrian Security Strategy, 2013). In addition, Austria supported NATO missions, including in Afghanistan and the Western Balkans.

NATO's southern region traditionally includes Portugal, Spain, Italy, Greece, and Turkey. The Croatia and Slovenia accession formally added another member of the southern region to Southern Europe's Joint Armed Forces (AFSOUTH). The focus on NATO's southern flank was a step towards a global Alliance, with a firm emphasis on the interests of collective defence without citing geographical boundaries. This could be a force in both a political and an operational sense. In the light of changes in the NATO and the United States' strategy, the Mediterranean region played a crucial role in terms of deploying allied forces in the Middle East, the periphery of Europe (e.g., in the Balkans), as well as in the countries of the Maghreb and Africa south of the Sahara. This enormous area also offered many opportunities for foreign and security policy in terms of solving the Cyprus problem (Pickering, 2000), more effectively influencing the Middle East process. All this, in turn, had an impact on European security and the role of the US as a global power. The Mediterranean region is a natural 'foyer' for deploying forces in the Persian (Arab) and Caspian Gulf regions. During Operation Desert Shield and Desert Storm, approximately $90 \%$ of the forces and materials necessary for the operation were transported 
through the region. For this reason, in Athens in June 1993, during the meeting of NATO foreign ministers, it was emphasized that Europe's security is closely related to the Mediterranean countries (North Atlantic Council, 1993).

Graz Triangle

The process of shaping the specific position of the Graz Triangle countries is the result of adaptation to these changes. It was initiated by the Croatian and Slovenian states creation and the European integration process. The accession of Croatia to the EU in 2013 strengthened the need to develop new cooperation mechanisms. Austria, Croatia, and Slovenia cooperate very closely on foreign policy issues. The European Union's enlargement towards South-Eastern European countries is especially strongly supported by both countries. Austria and Slovenia have taken several joint initiatives (Foreign and European Policy Report 2019, 2020). However, in March 2015, during the meeting of Austria, Croatia, and Slovenia's heads of government and the European Union Commissioner of Energy, the Austrian chancellor firmly opposed the joint Croatian-Slovenian nuclear power plant Krško. On the other hand, the heads of government agreed on the development of renewable energy sources. In addition, all the meeting participants emphasized the energy integration significance at the EU level aiming at the Energy Union implementation (Vlada, 2015). Therefore, except Austria, the rest of the Graz Triangle countries adopted the 3SI, announced the same year, and officially adopted it in 2016 in the Croatian capital as a project that will reduce energy dependence on oil and gas imports from Russia. Moreover, an initiative that will develop transport and digital infrastructure from North to South. In addition, these countries interpreted the 3SI as the implementation of a 'vision of a whole, free and peaceful Europe' (Zbińkowski, 2019). On the other hand, in terms of cooperation with the Central and Eastern European countries, Austria wants to be a bridge between this region and the West. Moreover, in the context of MENA, Vienna, due to its experience and commitment to the region, can also play an important role both for the other Graz Triangle countries and for the entire 3SI area. A significant reason for closer cooperation between the Central and South-Eastern European countries in the energy area was the experience of interruptions in gas supplies in 2009. This was due to the Russian-Ukrainian conflict. It was then that the concept of building a North-South gas corridor was born, which is currently being implemented under the 3SI. Moreover, in today's conditions, both in the energy and geopolitical areas, Croatia and Slovenia, as Mediterranean countries, will be increasingly interested in developing relations with the MENA, including the UAE (Sadecki, 2013).

Analysing the research subject and the position of Central and Eastern Europe in the EU in the context of the 3SI, Grgic emphasizes that both the rationalist and 
normative foundations of the latest wave of sub-regionalism have changed significantly compared to previous cases of cooperation (Grgić, 2021). The Graz Triangle should be seen in a broader perspective as a significant element of the 3SI. Therefore, cooperation with partners in the Middle East should take place within the framework of the 3SI, thus including the countries of the Graz Triangle. It should be noted that the countries of the 3SI have enormous potential to shape the Common Foreign and Security Policy of the EU. Moreover, the Visegrad Group activities in the Middle East, which in 2010 started cooperation with Egypt, Israel, and Lebanon, should become a part of 3SI actions. In 2011, the V4 group recognized the Persian Gulf Cooperation Council, including the UAE, as a strategic partner. In July 2017, the first V4 and Israel summit at the heads of government level was held in Budapest. Moreover, in July of the same year, the Visegrad Group met with Egyptian President Abdel Fattah Sisi. Therefore, the experience of the V4 countries with the MENA region should be used and extended to a broader form of cooperation within the 3SI (Krzymowski, 2021, pp. 110-111). The United States sees the eastern Mediterranean region as an area of global rivalry with Russia and China. Washington is striving to create a regional zone of energy and military security. Within this zone, the South-Eastern European countries will have protection against Russia and China, and in practice - given the situation in the region - most likely also against Turkey. Russia is counting more and more on Turkey leading to a NATO crisis and a collapse of the Alliance's political unity (Wójcik, 2020).

Geopolitical changes require both the Graz Triangle countries and the UAE to define priorities in foreign policy strategies that are determined by national interests. What identifies their roles is their political and economic potential and strategic location. However, political will is also a significant factor. Moreover, taking over a specific role is also a response to the external activity of other states, especially in bilateral relations.

\subsection{The Discussion of Research Results}

When discussing this topic in the context of the research results obtained, it must be admitted that after the collapse of Yugoslavia, Austria assumed responsibility for the Balkans. Its role grew along with the deepening of the European integration process in this region. Moreover, as Emil Brix (2016, pp. 243-244) points out, Austria in the broader geopolitical and international dialogue dimension has chosen the position of a bridge between different cultures and religions. Zgurić, Kos-Stanišić, and Domjančić (2015, p. 14) rightly note that the Middle East has a significant impact on the global architecture of international security and international relations. And the EU is taking steps to become a crucial player there. Therefore, Croatia as a member of the European Union should be active in the Middle East. On the other 
hand, Bojinović Fenko and Šabič (2017, p. 57) emphasize that in 2004, following Slovenia's NATO and EU accession, the country lost its clear strategic goals of foreign and security policy. Moreover, because of the high dynamics of changes in international relations and new challenges, Slovenia faced new foreign policy priorities. Finally, Mandaci and Rusi Karacalarli (2017, p. 495) emphasize that the Gulf states are increasingly interested in the Western Balkans and Central and Eastern Europe not only due to new areas of economic cooperation, including investment, but because of deepening political relations in broader geopolitics.

Due to the absence of scientific analysis in the literature, there is a lack of opportunity to conduct discussion and polemics. At the same time, it makes the presented research results unique and meaningful. Thus, they constitute both a crucial contribution to science and valuable material for practitioners of international relations. The results of the research show that the 3SI is not a prerequisite for better and deeper cooperation between the UAE and Austria, Croatia, Slovenia. However, it enables a wider range of possible projects to be implemented jointly. Moreover, in this context, it gives this part of the 3SI a strategic dimension for the UAE. It should also be noted that, especially during the presidency of Donald Trump, the 3SI and relations with the UAE were of major importance for US foreign and security policy. Therefore, President D. Trump personally became involved in the Three Seas project and the normalization of relations between the UAE and Israel. It assumed geopolitical and geo-economic implications. It was to become one of the elements of maintaining American influence in the Euro-Asian area. From the UAE's point of view, the country is diversifying its alliances. Therefore, the UAE is not limited to concluding partnerships in Central and Eastern Europe only with states allied with the US. Also, when selecting projects for collaboration, it is not solely guided by the Washington endorsement condition. The UAE's strategy is based on its own geopolitical and economic calculations. On the other hand, from the point of view of 3SI countries, it is important that the UAE is an ally for partners in the Euro-Atlantic area.

\section{Conclusion}

This study attempted to provide a new perspective on the relations between Austria, Slovenia, and Croatia (Graz Triangle) and the UAE. Both Central and Eastern Europe and the Middle East, including the Persian (Arab) Gulf region, were directly experiencing the end of the bipolar world order. In both geographic areas, a game started for the new world order. After 25 years, on the Croatia and Poland initiative, the Central and Eastern European countries started a new cooperation formula called the Three Seas Initiative, which is part of the 'New Europe' concept implementation. At that time, the UAE, recognizing the new project as attractive, 
began to dynamize relations with 3SI countries. Five years later, in September 2020, the geopolitical landscape of Central Eastern Europe, the Middle East and North Africa is rapidly changing. The agreement between the UAE and Israel impacts the emerging new regional architecture of international relations. Both processes influence the new global balance of power and competitions between global great powers. The Graz Triangle, due to its location and relations development with the MENA area, should be a significant element of the 3SI's Mediterranean dimension. Moreover, it adds the possibility of a complementary approach to the European Neighbourhood Policy, considering both its eastern and southern dimensions. In addition, the Graz Triangle states are in the middle of a new strategic game in which the UAE also takes part, influencing the current geopolitical situation, both in the Mediterranean region and in transatlantic relations. Therefore, the deepened cooperation between the Graz Triangle states and the UAE may bring positive value to all parts, in the form of broader influence in international relations. The results presented in this paper should inspire other researchers to continue in-depth analyses of the 3SI in the context of its role and importance in relations with Middle East partners.

\section{REFERENCES}

Asmus, R. (1997). NATO - Koncepcja Bezpieczeństwa w XXI wieku. Warszawa, Centrum Stosunków Międznar. Inst. Spraw Publicznych.

Austrian Embassy in Abu Dhabi. (2020a). Economy. Available at: https://www.bmeia. gv.at/en/oeb-abu-dhabi/austria-in-vae/economy/\#c969844 (retrieved 7 May 2020).

Austrian Embassy in Abu Dhabi. (2020b). Visit of Federal Chancellor Kurz. Available at: https://www.bmeia.gv.at/en/oeb-abu-dhabi/news/ (retrieved 4 May 2020).

Austrian Security Strategy. (2013). Security in a new decade - Shaping security. Federal Chancellery of the Republic of Austria, Vienna. Available at: https://www.bundesheer.at/pdf_pool/publikationen/sicherheitsstrategie_engl.pdf (retrieved 5 April 2021).

Barnett, M. \& Finnemore, M. (2004). Rules for the world: International organizations in global politics. Ithaca, NY, Cornell University Press.

Bojinović Fenko, A. \& Šabič, Z. (2017). Slovenia’s Foreign Policy Opportunities and Constraints: The Analysis of an Interplay of Foreign Policy Environments. CIRR, XXIII (79), pp. 41-72. DOI: 10.1515/cirr-2017-0014.

Bourdieu, P. (2004). Science of Science and Reflexivity. Chicago, University of Chicago Press. 
Brix, E. (2016). The State of Austrian Foreign and Security Policy in Times of Geopolitical Change. In Bischof, G. \& Karlhofer, F. (eds) Austrian Studies Today (pp. 239247). New Orleans, University of New Orleans Press. DOI: 10.2307/j.ctt1n2txjc.22.

Bueger, C. \& Gadinger, F. (2014). International practice theory: New perspectives. Basingstoke, Palgrave Macmillan.

Conway, M. \& Feigert, F. (1987). Political Analysis: An Introduction. Boston, Allyn \& Bacon.

Dubai Chamber. (2016). Dubai, Slovenia Pursue Stronger Bilateral Trading Ties. Available at: https://www.dubaichamber.com/whats-happening/chamber_news/dubaislovenia-pursue-stronger-bilateral-trading-ties (retrieved 17 May 2020).

Embassy of Slovenia. (2019). Slovenia and UAE negotiating cooperation on artificial intelligence, business, and tourism. Available at: http://www.abudabi.veleposlanistvo.si/index.php?id=5519\&L=1\&tx_ttnews\%5Btt_news\%5D=35036\&cHash=5811 895c644e1f1a0ada29df99d8af64 (retrieved 14 May 2020).

European Commission. (2021). First Croatian LNG terminal officially inaugurated in Krk island. Available at: https://ec.europa.eu/inea/en/news-events/newsroom/firstcroatian-lng-terminal-officially-inaugurated-krk-island (retrieved 12 March 2021).

Foreign and European Policy Report 2019. (2020). Report by the Federal Minister for European and International Affairs. Vienna. Available at: https://www.bmeia.gv.at/ fileadmin/user_upload/Zentrale/Publikationen/AEPB/APB_2019_EN_integral.pdf (retrieved 15 March 2021).

Fritsch, W. (1988). The new minilateralism and developing countries. Washington, Institute for International Economics.

Górka, M. (2018). The Three Seas Initiative as a Political Challenge for the Countries of Central and Eastern Europe. Politics in Central Europe, 14(3), pp. 55-73. DOI: $10.2478 /$ pce-2018-0018

Grgić, G. (2021). The Changing Dynamics of Regionalism in Central and Eastern Europe: The Case of the Three Seas Initiative. Geopolitics. DOI: 10.1080/ 14650045.2021.1881489

Gulfnews. (2015). UAE, Slovenia discusses cooperation. Available at: https://gulfnews. com/business/uae-slovenia-discuss-cooperation-1.1587279 (retrieved 17 May 2020).

Gulfnews. (2017). UAE, Croatia to avoid double taxation. Available at: https://gulfnews. com/uae/government/uae-croatia-to-avoid-double-taxation-1.2058865 (retrieved 11 May 2020).

Hassan, B. (2020). Abdullah bin Zayed receives Slovenian FM. WAM. Available at: https://wam.ae/en/details/1395302816206 (retrieved 18 April 2020).

HINA. (2018). EXPO 2020 in Dubai to Help Croatian Companies Do Business in UAE. Total Croatia News. Available at: https://www.total-croatia-news.com/business/ 
27708-expo-2020-in-dubai-to-help-croatian-companies-do-business-in-uae (retrieved 17 May 2020).

Hussein, H. \& Hatem, M. (2019). Gargash meets Slovenian Minister of Foreign Affairs. WAM. Available at: https:/wam.ae/en/details/1395302798558 (retrieved 18 May 2020).

Jakóbik, W. (2019). Nie dajcie się nabrać Węgrom. BiznesAlert.pl. Available at: https:// biznesalert.pl/wegry-import-lng-chorwacja-katar-gazprom-umowa-gazowa-pacsenergetyka-gaz-atom/ (retrieved 15 March 2021).

Jakóbik, W. (2020). Śródziemnomorski sojusz gazowy powstaje ze sporem z Turcja w tle. Available at: https://biznesalert.pl/eastmed-gas-forum-karta-forum-gazowegowschodniego-morza-srodziemnego-energetyka-gaz/ (retrieved 15 March 2021).

Keohane, N. (2012). Thinking about Leadership. Princeton, Princeton University Press.

Krzymowski, A. (2020a). The European Union and the United Arab Emirates as Civilian and Soft Powers Engaged in Sustainable Development Goals. Journal of International Studies, 13(3), pp. 41-58. DOI: 10.14254/2071-8330.2020/13-3/3

Krzymowski, A. (2020b). Expo2020 Dubai on the journey to achieve the United Arab Emirates' Soft Superpower. University of Sharjah Journal for Humanities \& Social Sciences, 17(2A). https//:doi.org/10.36394/jhss/17/2A/13

Krzymowski, A. (2020c). Sustainable Development Goals in Arab Region - United Arab Emirates' Case Study. Problemy Ekorozwoju, 15(1), pp. 211-220. DOI: 10.35784/ pe.2020.1.22

Krzymowski, A. (2021). The Visegrad Group countries: The United Arab Emirates Perspective. Politics in Central Europe, 17(1), pp. 107-126. DOI: 10.2478/pce-20210005

Kurečić, P. (2018). The Three Seas Initiative: geographical determinants, geopolitical foundations, and prospective challenges. Hrvatski geografski glasnik, 80(1), pp. 99124. DOI: 10.21861/Hgg.2018.80.01.05

Mandaci, N. \& Rusi Karacalarli, E. (2017). Gulf Region and Western Balkans: A Current History of Interregional Relations. DEU Journal of GSSS, 19(3), pp. 491-514.

Ministry of Economy. (2021). Trade Relations Dashboard. Available at: https:/www. economy.gov.ae/english/Knowledge-Section/TradeRelations/Pages/Trade-Relation.aspx (retrieved 7 August 2021).

MOFAIC. (2017a). H.H. Sheikh Abdullah bin Zayed receives Slovenian PM. Available at: https://www.mofaic.gov.ae/en/MediaHub/News/2017/2/14/14-02-2017-UAESlovenia (retrieved 18 May 2020).

MOFAIC. (2017b). Abu Dhabi Crown Prince, Austrian Federal Chancellor seek stronger ties. Available at: https:/www.mofaic.gov.ae/en/MediaHub/News/2017/5/26/2605-2017-UAE-Austrian-Federal (retrieved 7 May 2020).

MOFAIC. (2017c). 9th Joint Emirati-Austrian Committee concludes in Vienna. Available at https://www.mofaic.gov.ae/404?item=\%2fmediahub $\% 2$ fnews $\% 2 \mathrm{f} 2017 \% 2 \mathrm{f}$ 
$11 \% 2 \mathrm{f} 22 \% 2 \mathrm{f} 22-11-2017$-uae-vienna\&user $=$ extranet $\% 5 \mathrm{c}$ Anonymous\&site $=$ LDSC (retrieved 5 May 2020).

MOFAIC. (2018a). Chancellor of Austria receives H.H. Sheikh Abdullah bin Zayed. Available at: https://www.mofaic.gov.ae/en/MediaHub/News/2018/2/3/03-022018-UAE-Austria (retrieved 5 May 2020).

MOFAIC. (2018b). His Highness Sheikh Mohamed bin Zayed, Austrian Chancellor witness signing of ADNOC-OMV agreements. Available at: https://www.mofaic.gov. ae/en/MediaHub/News/2018/4/30/30-04-2018-UAE-ADNOC-OMV-agreements (retrieved 7 July 2020).

MOFAIC. (2019). His Highness Sheikh Mohamed bin Zayed, Austrian Chancellor attend signing of MoUs between ADNOC, OMV, Borealis. Available at: https://www. mofaic.gov.ae/en/MediaHub/News/2019/3/24/24-03-2019-UAE-Austria (retrieved 5 May 2020).

Naím, M. (2009). Minilateralism. The magic number to get real international action. Foreign Policy, July-August.

North Atlantic Council. (1993). Press Communiqué M-NAC-1(93) 38, Ministerial Meeting of the North Atlantic Council, Greece, 10 June.

Pickering, T. (2000). Greece and the United States: A partnership for Southeastern Europe, Greece, 2 February.

PolskieRadio24.pl. (2019). Trójmorze, NATO $i$ energetyka. Zacieśniamy wspótprace $z$ Chorwacja. Available at: https://www.polskieradio24.pl/5/1222/ Artykul/2335008, Trojmorze-NATO-i-energetyka-Zaciesniamy-wspolprace-zChorwacja (retrieved 7 March 2021).

Pouliot, V. (2007). "Sobjectivism": Toward a constructivist methodology. International Studies Quarterly, 51(2), pp. 359-384.

Radio.net Zadnja izmjena. (2013). Austrian, Croatian, and Slovenian premiers to meet on regular basis. Available at: https://www.tportal.hr/vijesti/clanak/austrian-croatian-and-slovenian-premiers-to-meet-on-regular-basis-20130823 (retrieved $23 \mathrm{Au}-$ gust 2013).

Ringmar, E. (2014). The search for dialogue as a hindrance to understanding: Practices as inter-paradigmatic research program. International Theory, 6(1), pp. 1-27.

Rosenau, J. N. (1981). The Study of Political Adaptation. New York, Pinter, Londyn \& Nichols.

Rühe, V. (1998). Die Allianz braucht ein neues strategisches Konzept. Frankfurter Allgemeine (28 März).

Sadecki, A. (2013). Perspektywy współpracy Chorwacji z Grupą Wyszehradzką. KOMENTARZE OSW. Available at: https://www.osw.waw.pl/pl/publikacje/komentarze-osw/2013-10-03/perspektywy-wspolpracy-chorwacji-z-grupa-wyszehradzka (retrieved 3 October 2013). 
Salman, N. (2019). UAE convenes Joint Economic Committee with Slovenia. WAM. Available at: https://wam.ae/en/details/1395302798703 (retrieved 17 May 2020).

Schatzki, T. (2001). Introduction: Practice theory. In Schatzki, T., Cetina, K. K. \& von Savigny, E. (eds) The practice turn in contemporary theory (pp. 1-14). London, Routledge.

Schatzki, T., Cetina, K. K. \& von Savigny, E. (eds). (2001). The practice turn in contemporary theory. London, Routledge.

Seroka, M. (2020). Chorwacja: dobre perspektywy terminalu LNG na wyspie Krk. Analizy. OSW. Available at: https://www.osw.waw.pl/pl/publikacje/analizy/2020-06-24/ chorwacja-dobre-perspektywy-terminalu-lng-na-wyspie-krk (retrieved 15 January 2021).

The Slovenia Times. (2015). Slovenia and UAE Sign Economic Cooperation Agreement. Available at: https://sloveniatimes.com/slovenia-and-uae-sign-economic-cooperation-agreement/ (retrieved 11 May 2020).

Total Croatia News. (2019). Slovenia Opens Embassy in Abu Dhabi, First in Gulf. Available at: https://www.total-slovenia-news.com/politics/4865-slovenia-opens-embassy-in-abu-dhabi-first-in-gulf (retrieved 7 May 2020).

Turner, S. (1994). The social theory of practices: Tradition, tacit knowledge, and presuppositions. Chicago, University of Chicago Press.

Vlada. (2015). Prime ministers of Austria, Croatia and Slovenia meet to discuss energy priorities. Available at: https://vlada.gov.hr/news/prime-ministers-of-austriacroatia-and-slovenia-meet-to-discuss-energy-priorities/16643 (retrieved 15 March 2021).

Wójcik, T. (2020). Czy Turcja przejmie gazociag EastMed? BiznesAlert.pl. Available at: https://biznesalert.pl/wojcik-turcja-gazociag-eastmed-morze-usa-iran-turcja-rosjaenergetyka/ (retrieved 15 March 2021).

Zbińkowski, G. (2019). The Three Seas Initiative and its Economic and Geopolitical Effect on the European Union and Central and Eastern Europe. Comparative Economic Research. Central and Eastern Europe, 22(2). http://doi.org/10.2478/cer-20190015

Zgurić, B., Kos-Stanišić, L. \& Domjančić, S. (2015). Comparison of Croatian foreign policy towards Latin America and the Middle East (2001-2012). Europske studijeEuropean Studies, 1(1), pp. 5-32.

Mailing Address:

Adam Krzymowski is a former ambassador and is currently lecturing and researching at the Department of International Studies, Zayed University. E-mail: ak7@vp.pl 